\title{
Pre- and Post-Construction Assessment of Nutrient Concentrations at Shallow Water Habitat Restoration Sites on the Lower Missouri River
}

\author{
Nathan J. C. Gosch ${ }^{1 *}$, Dane M. Morris ${ }^{1}$, Todd R. Gemeinhardt ${ }^{1}$, Joseph L. Bonneau ${ }^{2}$ \\ ${ }^{1}$ US Army Corps of Engineers, Kansas City, USA \\ ${ }^{2}$ US Army Corps of Engineers, Yankton, USA \\ Email: *Nathan.J.Gosch@usace.army.mil
}

Received December 5, 2012; revised January 6, 2013; accepted January 14, 2013

\begin{abstract}
Loss of shallow water habitat (SWH) is hypothesized as a factor contributing to the decline of native Missouri River fishes, including the endangered pallid sturgeon. As a result, the restoration of SWH is a high priority in this large river system. Restoration activities often include constructing side channel chutes; however, limited information exists on the potential negative, unintended effects of chute construction activities on water quality. This study was designed to better understand the possible effects of chute construction, both initially and as chute development continues, on Missouri River nutrient concentrations. Our first objective was to determine if the addition of sediment from proposed chute locations to river water samples (i.e., elutriate samples) increased nutrient concentrations relative to water-only river samples collected just upstream of the proposed chute locations or river water samples collected from eight long-term water quality monitoring stations. Our second objective was to determine if nutrient concentrations of river samples monitored during 2009 and 2010 increased after water passed through previously-constructed chutes. Nutrient concentrations of elutriate samples were not significantly higher than river water samples collected just upstream of the proposed chute locations; the same was true for Missouri River water samples collected from seven of eight long-term water quality monitoring stations. Furthermore, monitoring of nutrient concentrations collected from water samples at the outlet of previously-constructed chutes were not significantly higher than water samples collected at the upstream inlet of these chutes. Our results suggest that individual SWH chute construction projects designed to restore some of the natural form and function of the Missouri River are unlikely to significantly increase Missouri River nutrient concentrations initially or as these chutes continue to develop.
\end{abstract}

Keywords: Shallow Water Habitat; Missouri River; Restoration; Nitrogen; Phosphorus

\section{Introduction}

During the $20^{\text {th }}$ century, the Missouri River was dramatically altered for the purposes of flood control, hydropower generation, water supply, and commercial navigation. These alterations included the construction of six mainstem reservoirs in the upper Missouri River basin and extensive channelization and bank stabilization below Sioux City, IA as part of the Bank Stabilization and Navigation Project (BSNP) [1-5]. Additionally, many tributaries of the Missouri River experienced damming and channel modification [1,5]. Consequently, Missouri River hydrology and sedimentary processes were highly altered. Historically, the Missouri River transported a dramatically larger sediment load compared to current levels [6]. Missouri River mainstem dams trap 100 - 150 million metric tons of sediment per year (about $50 \%$ of the

${ }^{*}$ Corresponding author. historic sediment load), while major and minor engineering projects and soil-retention measures account for the rest of the trapped sediment [4].

As a result, habitat diversity declined as the lower Missouri River shifted from extensive areas of warm, shallow and turbid habitat with braided channels and large sandbars (i.e., shallow water habitat $[\mathrm{SWH}]$ ) to colder, deeper and clearer habitats within a single channel $[3,5,7,8]$. Nearly 3 million acres of natural riverine and floodplain habitat were altered and 520,000 acres lost due to land-use changes, channelization, and levee building $[9,10]$ negatively impacting many species native to the basin $[5,11,12]$. These altered and lost habitats are considered important to primary and secondary productivity, prey fish production, and nursery areas for native fishes, including the endangered pallid sturgeon Scaphirhynchus albus [12-15]. The 1990 listing of the pallid sturgeon as endangered prompted the US Fish and Wild- 
life Service (USFWS) to issue a Biological Opinion in 2000 and an amendment in 2003 (collectively referred to as BIOP) on the operation of the Missouri River system $[8,14]$. The BIOP recommended a large scale habitat restoration project to increase sediment loads and create approximately 20,000 acres of SWH, which includes side channel chutes, backwaters, depositional sandbars disconnected from the shoreline and low-lying depositional areas near the shoreline [16], between Sioux City, IA and the mouth of the Missouri River to improve habitat for pallid sturgeon. In response, the US Army Corps of Engineers (USACE) began actively creating SWH on the Missouri River by modifying or removing existing control structures and creating off-channel habitats, such as chutes and backwaters.

Unfortunately, large scale habitat restoration projects often create complex socioeconomic and ecological issues because of the potential effect on a diverse group of stakeholders. Varying stakeholder interests often create conflicts for decision makers, resulting in slowed or halted projects. For example, the Missouri Clean Water Commission expressed concern during the 2007 Jameson Island chute construction project over potential effects of sediment discharge from SWH restoration sites on Missouri River water quality as sediment discharges often exceed 500,000 metric tons per project [17]. Concerns mainly focused on potential localized effects of sediment discharges on Missouri River nutrient concentrations as well as potential downstream effects on the Gulf of Mexico hypoxic zone [5]. Those opposing SWH projects also contended that sediment discharges during habitat construction violated state and federal water pollution control laws.

Subsequently, the USACE ceased construction on the Jameson project, halted all habitat creation efforts in the state of Missouri and requested independent guidance from the National Research Council (NRC) on Missouri River sediment management and the potential effects of SWH projects, both locally and downstream to the Gulf of Mexico [5]. The NRC responded by assigning an independent panel of experts to provide guidance on these matters. The NRC concluded that, based on the information available, SWH projects are unlikely to have significant, negative effects on Missouri River water quality or the Gulf of Mexico hypoxic zone; however, a limited knowledge of the effects of sediment release from SWH restoration projects warrants monitoring of SWH construction activities to help guide management decisions within an adaptive management framework [5]. Furthermore, insight regarding sources and processes affecting Missouri River nutrient transport has local, regional and national ramifications for nutrient management efforts [18]. Thus, this study was part of a large monitoring effort and was designed to better understand the effects of chute construction, both initially and as chute development continues, on Missouri River nutrient concentrations. Our specific objectives were to determine if: 1) the addition of sediment from proposed chute locations to river water samples increased nutrient concentrations relative to water-only river samples collected just upstream of the proposed chute locations or river water samples collected from eight long-term water quality monitoring stations; and 2) nutrient concentrations of river samples monitored during 2009 and 2010 increased after water passed through previously-constructed chutes.

\section{Materials and Methods}

\subsection{Study Area}

The lower Missouri River extends approximately 1305 river kilometers (rkm) downstream of Gavins Point Dam, SD to the confluence with the Mississippi River at St. Louis, MO. Pre-construction assessment sites were Barney Bend (rkm 880), Wolf Creek (rkm 772), Benedictine Bottoms (rkm 686), Bakers Bend (rkm 454), Jameson Island (rkm 340) and Cora Island (rkm 10) because these sites are proposed locations for future chute projects (Figure 1). We also used data collected from eight lower Missouri River long-term water quality monitoring stations to provide a representative range of nutrient levels sampled during a wide variety of flow magnitudes. Selected monitoring stations (Rulo, NE [rkm 818]; Atchison, KS [rkm 681]; Sibley, MO [rkm 541]; Waverly, MO [rkm 472]; Glasgow, MO [rkm 364]; Marion, MO [rkm 257]; Hermann, MO [rkm 158]; and Weldon Springs, MO [rkm 79]) were routinely sampled from March-October, 2009-2011 and geographically interspersed among our proposed chute projects (Figure 1).

Post-construction assessment sites were previouslyconstructed chute sites of varying ages (California Bend [rkm 1046] was constructed in 1999, Tobacco Island [rkm 948] was constructed in 2000, Upper Hamburg Bend [rkm 893] was constructed in 1994 and Overton Bottoms [rkm 295] was constructed in 2003). The postconstruction assessment also included a natural chute, Lisbon Bottoms (rkm 351), that formed as a result of high flows during 1993 and 1996 [19]. All pre- and postconstruction sites as well as monitoring stations are referred to by first name hereafter.

\subsection{Pre-Construction Assessment}

Initial water and sediment sampling occurred at Jameson during 2007; additional sampling was conducted during March 2011 because of plans to extend the length of Jameson chute. Sampling also occurred at Barney during March 2011, at Benedictine during November 2011 and at Wolf, Bakers, and Cora during April 2012. Water samples were collected from the mainstem of the Missouri River upstream of the proposed construction sites. 


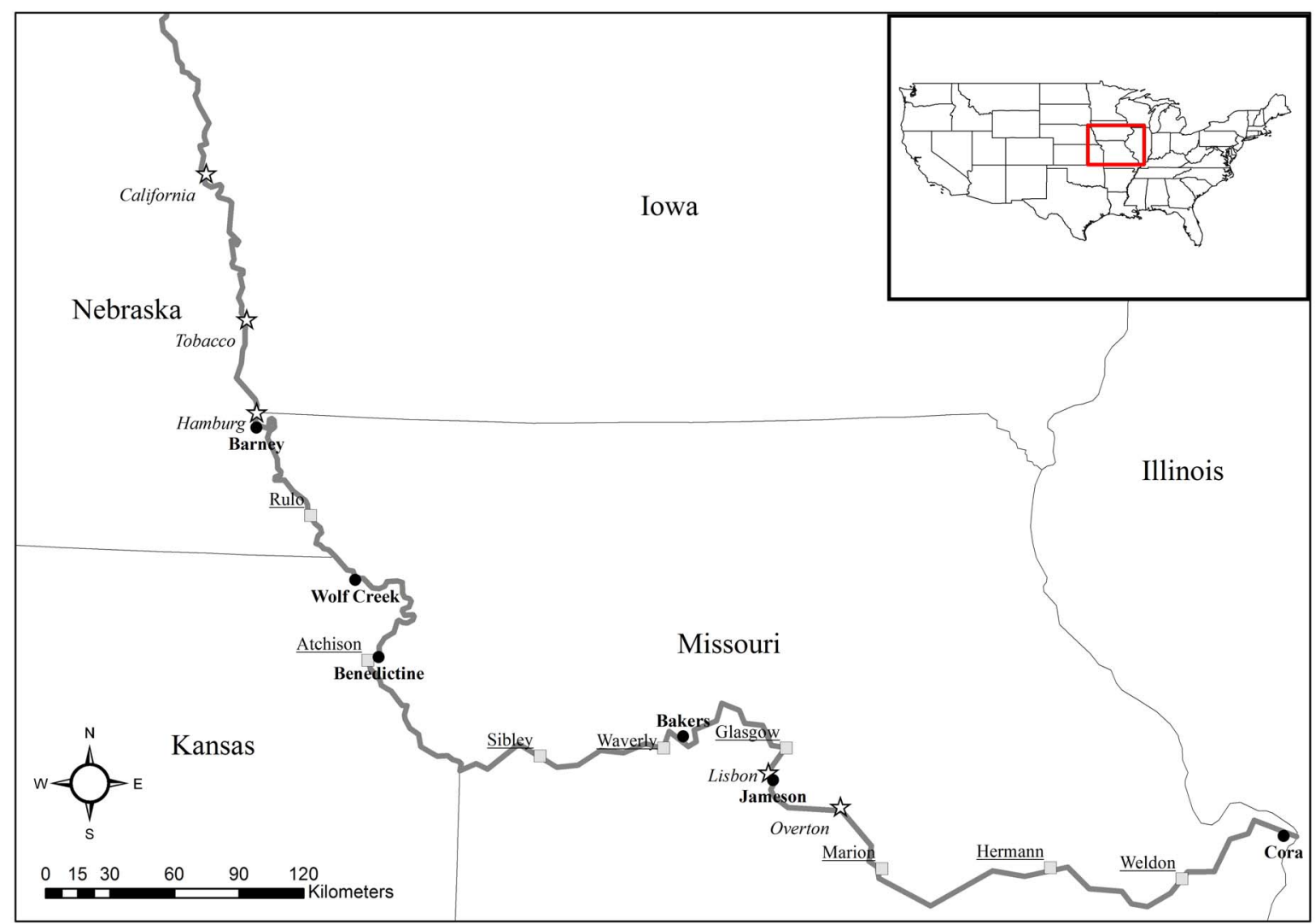

Figure 1. Map of lower Missouri River pre-construction sites (black-filled circles, bold labels), long-term water quality monitoring stations (gray-filled squares, underlined labels) and post-construction sites (white-filled stars, italicized labels).

Transects were established and surface grab samples $(0.1$ m) were collected at four evenly distributed locations across the mainstem to account for potential lateral variability. Samples were shipped to a contract laboratory and analyzed for total phosphorus (TP), total orthophosphorus (TOP), total Kjeldahl nitrogen (TKN) and, nitrate-nitrite $\left(\mathrm{NO}_{3}-\mathrm{NO}_{2}\right)$ according to US Environmental Protection Agency [USEPA] Methods 365, 365.3, 351 and 353, respectively. Total nitrogen (TN) was calculated by summing TKN and $\mathrm{NO}_{3}-\mathrm{NO}_{2}$ measurements for each sample. Sediment samples were collected from the proposed chute excavation area. Borings were collected at approximately $300-\mathrm{m}$ intervals along the proposed chute alignment. Continuous sample cores were collected with a 4-ft Geoprobe Macro-Core sampler. The borings were advanced to the depth of the saturated zone or a maximum of $6 \mathrm{~m}$. For each boring, an elutriate sample was prepared using boring sediment and water collected from the mainstem. The elutriate samples were prepared by the laboratory in accordance with established protocols [20]. A 1-L subsample of sediment was removed from the well-mixed, original boring sample. The sediment and unfiltered, mainstem water were combined at a 1:4 sediment-to-water volume ratio. The mixture was stirred vigorously for $30 \mathrm{~min}$ and allowed to settle for $1 \mathrm{~h}$. The supernatant was siphoned off without disturbing the settled material, and centrifuged to remove particulates prior to chemical analysis. The resulting elutriate samples were analyzed for the nutrients mentioned above.

A Kruskal-Wallis non-parametric analysis of variance (ANOVA) was used to compare nutrient concentrations among elutriate samples and mainstem water samples because the data often violated normality and/or equal variance assumptions. Similarly, a Kruskal-Wallis nonparametric ANOVA was used to compare nutrient concentrations among elutriate samples and water samples collected at monitoring stations located upstream and downstream of construction sites. At each monitoring station, samples were collected at monthly intervals (MarchOctober) during 2009-2011 allowing a comparison of elutriate samples with data collected during a wide range of flow magnitudes that represents the ambient conditions present at each site. Dunn's multiple comparison procedure was used for all pairwise comparisons.

\subsection{Post-Construction Assessment}

Surface grab samples were collected from construction sites at monthly intervals (April-November) during 2009 and 2010, except when high flows made it difficult to differentiate the chute from the mainstem. Within each 
chute, a surface grab sample was collected at the chute inlet and outlet to determine if there was any change in nutrient contributions after water had passed through the chutes. Surface grab samples were also collected from the mainstem above each chute location using the same transect method described above. Similar to the pre-construction assessment, water samples were analyzed by the contract laboratory for the nutrients described above; total suspended solids (TSS) were also measured and analyzed according to USEPA Method 160.2.

Multivariate analysis of variance (MANOVA) was used to assess differences among months and water sampling locations (e.g., mainstem, chute inlet, chute outlet) for TN, TP, and TSS for each site. For MANOVA, all subjects must be measured for all response variables [21]; thus, site could not be used as a MANOVA factor because all sites were not sampled during every month due to flow conditions. Pillai's trace test statistic was used because it is the most robust and most frequently used statistic for MANOVA analysis [21]. If the MANOVA was significant $(\alpha=0.05)$, individual (one-way or twoway) ANOVAs were used to assess differences in TN, TP and TSS concentrations for the significant MANOVA factor(s). Tukey's test was used for all pairwise comparisons.

\section{Results}

\subsection{Pre-Construction Assessment}

Elutriate and mainstem river water concentrations were

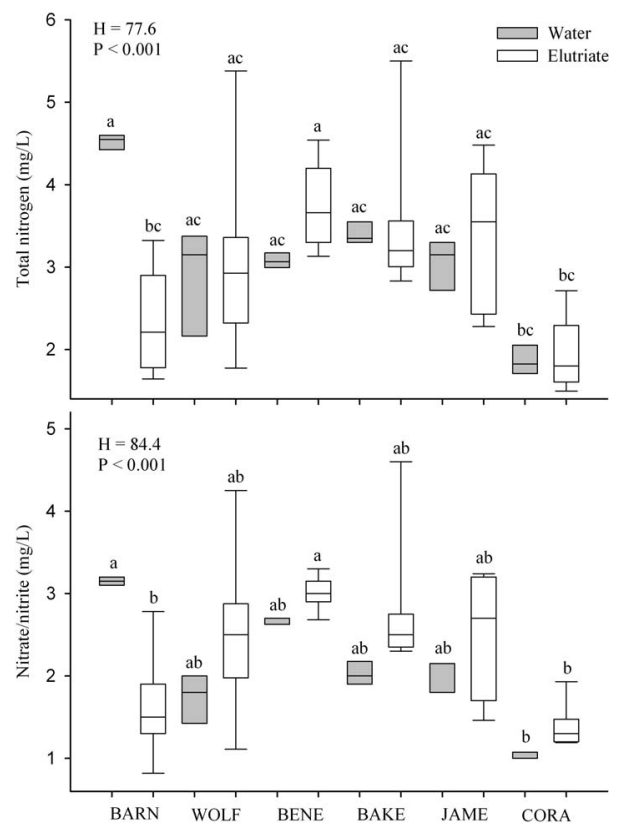

significantly different among sites for all analyzed nutrients (Figure 2). However, significant differences within a particular site were rare for $\mathrm{TN}, \mathrm{NO}_{3}-\mathrm{NO}_{2}$, and TOP. In these rare cases, Barney river water concentrations were higher than Barney elutriate samples (Figure 2). In contrast, significant differences within sites were common for TP; however, these differences were again the result of higher concentrations in the river water compared to the elutriate samples (Figure 2).

Elutriate and monitoring station concentrations were also significantly different for all analyzed nutrients (Figure 3). For TN, significant differences were rare when comparing elutriate concentrations to monitoring station concentrations (Figure 3). Similarly, significant differences were rare when comparing elutriate concentrations to monitoring station concentrations for $\mathrm{NO}_{3}-\mathrm{NO}_{2}$ (Figure 3). In contrast to $\mathrm{TN}$ and $\mathrm{NO}_{3}-\mathrm{NO}_{2}$, no monitoring stations had significantly lower TP or TOP concentrations compared to elutriate concentrations (Figure 3).

\subsection{Post-Construction Assessment}

All five sites were sampled during 2009, except Lisbon and Overton during November. During 2010, all sites were sampled, except Tobacco. Lisbon and Overton were not sampled during May 2010. Nutrient concentrations differed among months for each site; however, concentrations did not differ among sample locations at any site (Figure 4 and Table 1). The interaction term (month $\times$ sample location) for each MANOVA was not significant.

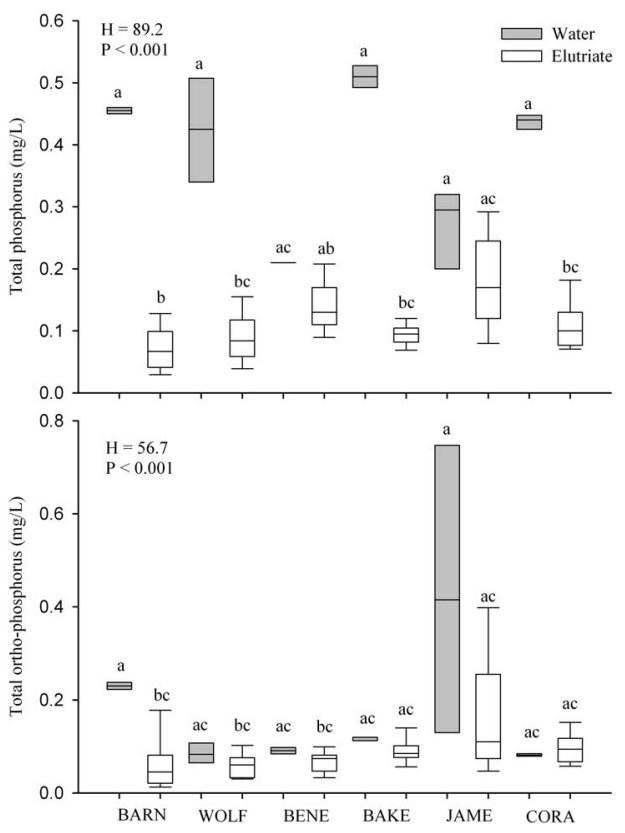

Figure 2. Box plots (showing $5^{\text {th }}, 25^{\text {th }}, 50^{\text {th }}, 75^{\text {th }}$ and $95^{\text {th }}$ percentiles) of total nitrogen, nitrate-nitrite, total phosphorus and total ortho-phosphorus concentrations for elutriate samples using sediment from pre-construction chute sites (BARN = Barney, WOLF $=$ Wolf, BENE $=$ Benedictine, BAKE $=$ Bakers, JAME $=$ Jameson and CORA $=$ Cora) and for water samples from adjacent, upstream Missouri River sites. Box plots with same letter are not statistically $(\alpha=0.05)$ different. 

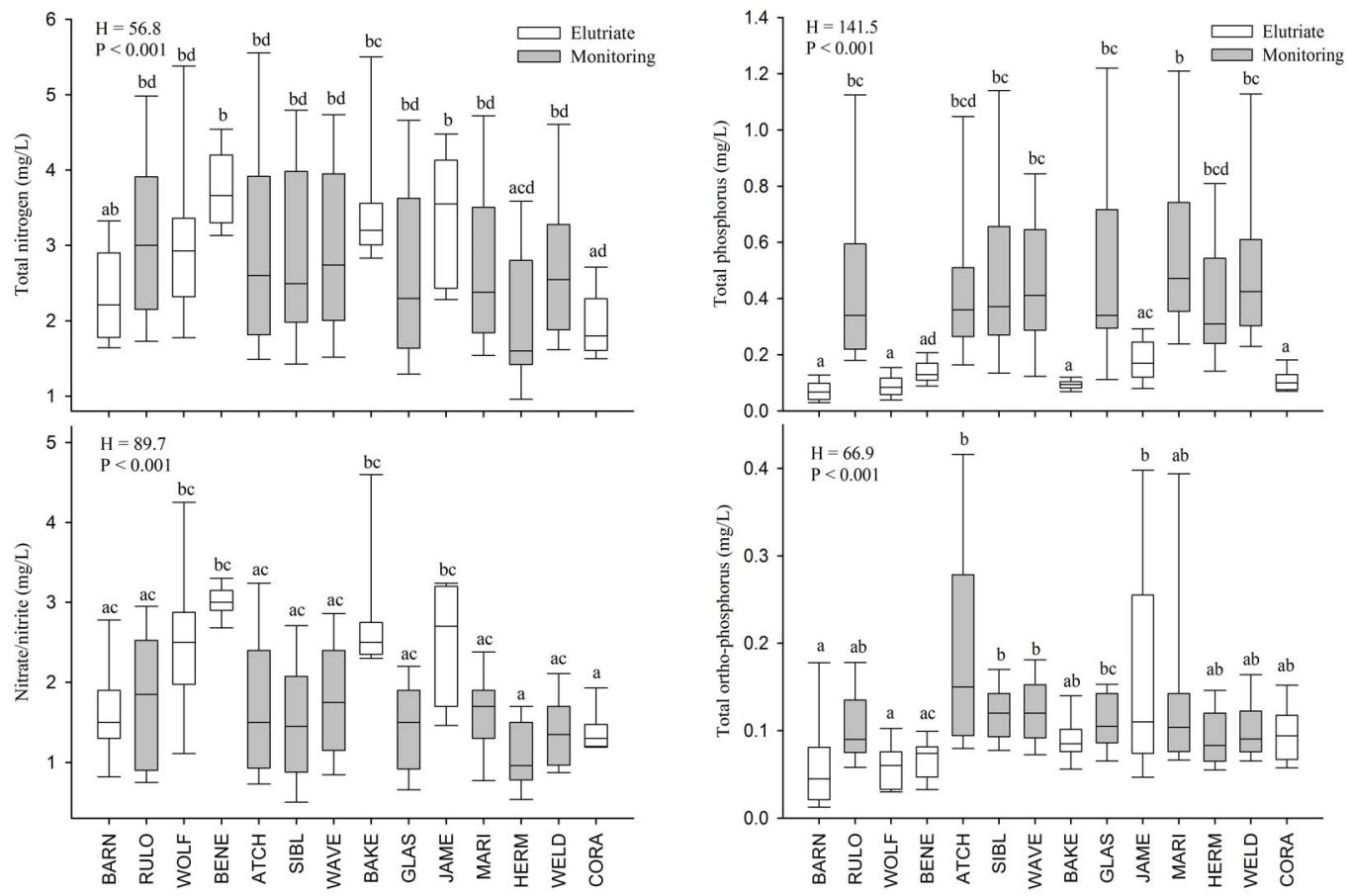

Figure 3. Box plots (showing $5^{\text {th }}, 25^{\text {th }}, 50^{\text {th }}, 75^{\text {th }}$ and $95^{\text {th }}$ percentiles) of total nitrogen, nitrate-nitrite, total phosphorus and total ortho-phosphorus concentrations for elutriate samples from pre-construction chute sites $(\mathrm{BARN}=\mathrm{Barney}$, WOLF $=$ Wolf, BENE = Benedictine, BAKE $=$ Bakers, JAME $=$ Jameson and CORA $=$ Cora) and water samples from Missouri River monitoring stations (RULO = Rulo, ATCH = Atchison, SIBL = Sibley, WAVE = Waverly, GLAS = Glasgow, MARI $=$ Marion, HERM = Hermann, WELD $=$ Weldon Springs $)$. Box plots with same letter are not statistically $(\alpha=0.05)$ different.

Table 1. Results of multivariate analysis of variance assessing differences in total nitrogen, total phosphorus, and total suspended solids among months and sample locations (i.e., mainstem, chute inlet, and chute outlet) for each post-construction site during 2009 and 2010.

\begin{tabular}{cccc}
\hline Site & Factor & F & P \\
\hline \multirow{2}{*}{ California } & Month & 22.5 & $<0.001$ \\
& Sample Location & 2.3 & 0.06 \\
\multirow{2}{*}{ Tobacco } & Month & 2.7 & 0.03 \\
& Sample Location & 1.3 & 0.35 \\
\multirow{2}{*}{ Hamburg } & Month & 13.1 & $<0.001$ \\
& Sample Location & 2.2 & 0.08 \\
Lisbon & Month & 7.9 & $<0.001$ \\
& Sample Location & 1.1 & 0.40 \\
\multirow{2}{*}{ Overton } & Month & 13.6 & $<0.001$ \\
& Sample Location & 1.3 & 0.33 \\
\hline
\end{tabular}

At California, concentrations of TN, TP and TSS differed among months sampled. Monthly differences in TN usually occurred when comparing 2009 sampling months to 2010 with few significant differences occurring among sampling months within a particular year (Figure 4). Monthly differences in TP were common with signifi- cantly higher concentrations during July and August of 2010 than any other month sampled (Figure 4). Monthly differences in TSS were also common with significantly higher concentrations during August 2009 than any other month sampled (Figure 4). At Tobacco, TN concentrations differed among months sampled. Monthly differences in TN were common with significantly higher concentrations during November 2009 than any other month sampled (Figure 4). In contrast, TP and TSS did not differ among months sampled (Figure 4). At Hamburg, concentrations of TN, TP and TSS differed among months. Monthly differences in TN were common with significantly higher concentrations during May and July of 2010 than any other month sampled (Figure 4). Monthly differences in TP and TSS were also common with significantly higher concentrations during July 2010 than any other month sampled (Figure 4). At Lisbon, concentrations of TN, TP and TSS differed among months. Monthly differences in TN, TP and TSS were common with significantly higher concentrations during July 2010 than any other month sampled (Figure 4). At Overton, concentrations of TN, TP and TSS differed among months. Monthly differences in TN, TP and TSS were common with significantly higher concentrations during July 2010 than any other month sampled (Figure 4). 

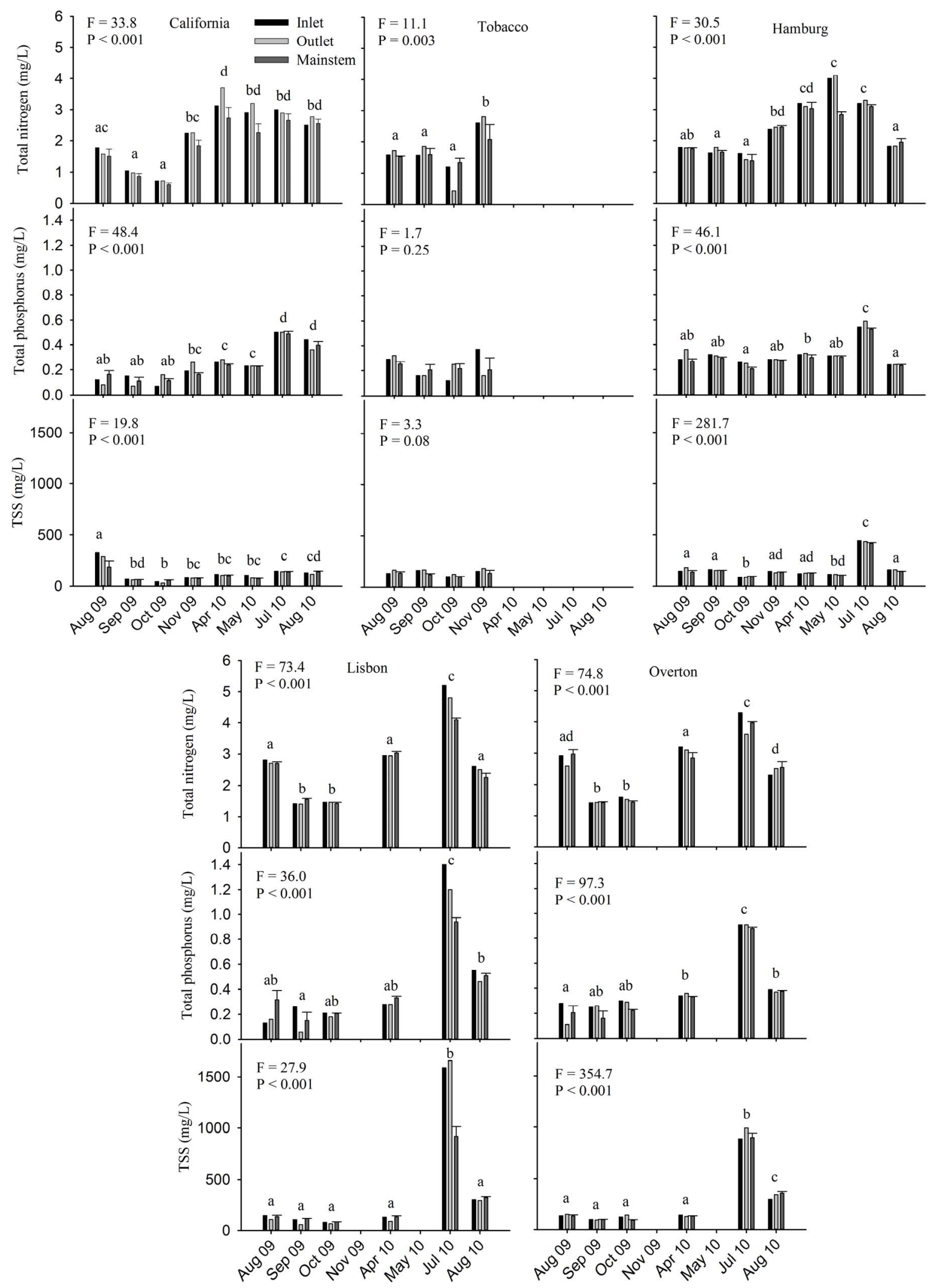

Figure 4. Total nitrogen, total phosphorus and total suspended solids (TSS) concentrations for chute inlet, chute outlet and adjacent, upstream Missouri River sites (mean + SE) at California, Tobacco, Hamburg, Lisbon and Overton chutes. Months with same letter are not statistically $(\alpha=0.05)$ different. 


\section{Discussion}

The addition of sediment from project locations to water samples collected from the mainstem of the Missouri River did not significantly increase nutrient concentrations (relative to water-only samples) during the preconstruction assessment suggesting that chute construction activities may have little local effect on Missouri River nutrient concentrations. Similarly, comparisons with monitoring stations found that elutriate TP and TOP concentrations were not usually higher than the ambient conditions found in the mainstem Missouri River. In fact, the elutriate TP concentrations were often drastically lower than concentrations sampled during a wide range of flow events at these monitoring stations. Phosphate has a high affinity for mineral surfaces and easily adsorbs to sediment particles and soil [22]. Phosphorus transport is often driven by the movement of particles in streams, particularly in sediment-rich systems [23]. Our TP and TOP results suggest that the introduction of sediment from habitat creation projects may cause phosphorus to bind with the sediment particles and settle out of suspension; these particles may then be transported as bedload or redeposited downstream of the project location.

Ambient $\mathrm{TN}$ and $\mathrm{NO}_{3}-\mathrm{NO}_{2}$ concentrations at monitoring stations were also similar to elutriate concentrations, except at Hermann. This could be a function of location because Hermann is located downstream of two major tributaries (Gasconade and Moreau rivers) that drain watersheds with relatively little agricultural activity and another major tributary (Osage River) with multiple reservoirs resulting in a potential dilution effect. Blevins et al. [24] suggested that total organic nitrogen and TN loadings between St. Joseph, MO and Hermann, MO experienced a dilution effect. Despite few significant differences in $\mathrm{TN}$ and $\mathrm{NO}_{3}-\mathrm{NO}_{2}$ concentrations, visual comparisons of box plots showed that median elutriate concentrations at Benedictine, Bakers and Jameson were often located near the upper range of concentrations sampled at our monitoring stations, which suggests that an increase in $\mathrm{TN}$ and $\mathrm{NO}_{3}-\mathrm{NO}_{2}$ concentrations in the Missouri River during chute construction may occur; however, the range of elutriate concentrations for these proposed construction sites still overlapped considerably with the range of monitoring station concentrations, especially for TN. Thus, the elutriate-monitoring comparisons further support the position that an increase in nutrient concentrations during chute construction is unlikely.

Even if chute construction activities were expected to significantly increase nutrient concentrations, this increase would likely be temporary because the major influx of sediment likely occurs during the initial dredging of the pilot chute and subsequent iterations of erosion and deposition as the chute is allowed to develop and widen. As a chute develops, control structures are usually already in place to limit the amount of flow into the chute and ensure that other authorized Missouri River purposes (e.g., navigation) are not jeopardized [17]. Some erosion will still take place as the chute continues to develop and maintain habitat through natural erosional and depositional processes; however, this sediment influx will likely be less compared to influxes occurring after the initial dredging of the pilot channel. Furthermore, chutes experience channel evolution processes [25] and may reach dynamic equilibrium (e.g., [19]) when erosional and depositional processes are approximately balanced; thus, chute sediment contributions may decrease with time as a chute approaches dynamic equilibrium and becomes more stable. Additionally, deposition within certain areas of a chute is also likely, which could partially offset some of the erosion that may continue in other areas of a chute.

The post-construction assessment yielded results similar to the pre-construction assessment because individual chutes had little effect on nutrient concentrations of water samples collected during post-construction monitoring. Sampling month was the only significant MANOVA factor at all five post-construction sites. Most of the statistical differences resulted from higher nutrient concentrations during the 2010 summer months, especially July; much of the lower Missouri River basin experienced heavy precipitation during this period (as evidenced by relatively high flows) likely causing increased runoff of nutrients. Numerous studies have identified precipitation as an important factor facilitating the transport of nitrogen and phosphorus to streams (e.g., [26-29]) with agriculture (e.g., farm fertilizer) identified as the dominant source of TN and TP throughout most of the Missouri River Basin [18,27]. In contrast, nutrient concentrations were not significantly different among sample locations at any of the five post-construction sites using $\alpha=0.05$. Similarly, Jacobson et al. [30] concluded that individual Missouri River chute construction projects are unlikely to significantly increase nitrogen and phosphorus concentrations. At most, the Jameson Island chute construction project increased TN and TP loads by $0.23 \%$ and $2.6 \%$, respectively, relative to annual loads at Hermann, MO [30]; these percentages assumed that all of the sediment was transported by the river in a single year and that nutrient concentrations in the soil were uniform with depth as samples were mainly taken from the fine material in the upper two-thirds of the excavated material. Typically, Missouri and Mississippi River sediment depositional and retention processes will disperse the sediment load over the course of years [5]. Furthermore, the Jameson Island chute construction project represented only $0.15 \%$ and $2.1 \%$ of the estimated annual TN and TP loadings, respectively, delivered to the Mississippi River from the Missouri River Basin [18]. 
Although the cumulative effects of sediment reintroduction from SWH restoration efforts on Missouri River water quality are unknown [30], our results support the recent conclusion of the NRC that the potential negative effects of sediment from SWH restoration projects on Missouri River water quality will likely be minimal [5]. In contrast, the potential benefits of these projects may be substantial. These SWH areas are expected to provide habitat for imperiled, native fishes, including the endangered pallid sturgeon. Additionally, SWH restoration projects will increase floodplain connectivity (e.g., [17]), which may also result in increased flood reduction benefits during high-water events. Restoration sites may also eventually serve as nutrient sinks as the chutes mature. Crites et al. [31] suggested that Buffalo Chute may have acted as a nutrient sink for TN and TP in the Mississippi River. Furthermore, spatially referenced regressions on watershed attributes (SPARROW) models using data from across the US indicated that stream channels were often net sinks for phosphorus [27]. In contrast, SPARROW models specific to the Missouri River basin indicated that stream channels may be a net source of phosphorus [18]. However, these models also indicated that small streams with discharges $\leq 1.13 \mathrm{~m}^{3} / \mathrm{s}$ were not significant sources of phosphorus because water velocities were likely insufficient to resuspend sediment; constructed SWH chutes are designed to develop into shallow $(<1.5 \mathrm{~m})$, slow-water $(<0.61 \mathrm{~m} / \mathrm{s})$ areas $[8,14]$. Therefore, constructed SWH chutes may ultimately have velocities insufficient for sediment resuspension, which may reduce the likelihood that constructed chutes become a significant source of phosphorus. Another potential benefit of SWH projects may include helping offset local sediment and turbidity shortages near dredging operations or other areas of channel degradation in the lower Missouri River [30]. Furthermore, some sediment will likely reach the Louisiana coastal wetlands resulting in a positive byproduct from SWH projects; however, sediment contributions from chute construction projects are small relative to historic sediment loads supplied by the Missouri River and will only yield a small amount of the sediment needed to restore the Louisiana coastal wetlands to a near-natural state [5].

The reduction of sediment transported by the Missouri River following the BSNP and dam construction is considered one of many important factors contributing to the loss of Louisiana coastal wetlands [5]. Since the 1930s, Louisiana coastal wetlands have declined by 1900 square miles with the loss of an additional 500 square miles expected over the next 50 years despite current restoration efforts [32]. As a result, sediment-oriented restoration measures have been suggested including Missouri River dam removal and the building of structures that allow sediment to bypass these dams [4,5]. Additionally, the
Gulf Coast Ecosystem Restoration Task Force [33] recognizes a sediment deficit and calls for increased and wiser use of sediments in habitat restoration projects. However, the possible effects of reintroduced sediment, including sediment from Missouri River restoration projects, on water quality and Gulf of Mexico hypoxia is important. The NRC has considered this issue and concluded that, based on available estimates, nutrient loads from Missouri River SWH restoration projects will likely not affect the areal extent of the hypoxic zone [5].

Gulf hypoxia, sediment management, nutrient loadings, and habitat restoration are just a handful of the many socioeconomic and ecological issues facing the Mississippi and Missouri River basins. Many issues within the basin are interconnected further complicating management decisions as well as difficulties or uncertainties in determining the effects of certain conditions or management actions on these issues. For example, annual monitoring of the areal extent of the hypoxic zone can be difficult because many factors (e.g., river discharge, local weather and wind conditions, and nutrient concentrations) can considerably affect the size of the hypoxic zone in a short time [5]. Despite the difficulties and uncertainties, the available information suggests that the construction of SWH restoration projects are unlikely to have a significant, negative effect on Missouri River water quality or contribute to Gulf hypoxia. These projects are intended to return some of the natural form and function of the Missouri River that was lost as a result of the BSNP and the construction of mainstem dams. Additionally, these projects are designed to meet the USFWS BIOP requirements by creating suitable habitat for young pallid sturgeon. Thus, SWH efforts could provide important local and far-reaching, downstream benefits to aquatic habitats and native species.

\section{Acknowledgements}

We thank Jason Farmer, Steve Fischer, George Williams and Chance Bitner for providing valuable comments on an earlier draft of this manuscript. This study was funded by the US Army Corps of Engineers Kansas City District. The contents of this report are not to be used for advertising, publication, or promotional purposes. Reference to trade names does not imply endorsement by the US Government. All product names and trademarks cited are the property of their respective owners. The findings of this report are not to be construed as an official Department of Army position unless so designated by other authorized documents.

\section{REFERENCES}

[1] L. W. Hesse and G. E. Mestl, "An Alternative Hydrograph for the Missouri River Based on the Precontrol 
Condition," North American Journal of Fisheries Management, Vol. 13, No. 2, 1993, pp. 360-366. doi:10.1577/1548-8675(1993)013<0360:AAHFTM $>2.3$. $\mathrm{CO} ; 2$

[2] D. L. Galat, L. H. Fredrickson, D. D. Humburg, K. J. Bataille, J. R. Bodie, J. Dohrenwend, G. T. Gelwicks, J. E. Havel, D. L. Helmers, J. B. Hooker, J. R. Jones, M. F. Knowlton, J. Kubisiak, J. Mazourek, A. C. McColpin, R. B. Renken and R. D. Semlitsch, "Flooding to Restore Connectivity of Regulated, Large-River Wetlands," Bioscience, Vol. 48, No. 9, 1998, pp. 721-733. doi: $10.2307 / 1313335$

[3] R. B. Jacobson and D. L. Galat, "Design of a Naturalized Flow Regime-An Example from the Lower Missouri River, USA," Ecohydrology, Vol. 1, No. 2, 2008, pp. 81104. doi:10.1002/eco.9

[4] R. H. Meade and J. A. Moody, "Causes for the Decline of Suspended-Sediment Discharge in the Mississippi River System, 1940-2007," Hydrologic Processes, Vol. 24, No. 1, 2010, pp. 35-49.

[5] National Research Council, "Missouri River Planning: Recognizing and Incorporating Sediment Management," The National Academies Press, Washington DC, 2011.

[6] L. A. Sprague, M. L. Clark, D. L. Rus, R. B. Zelt, J. L. Flynn and J. V. Davis, "Nutrient and Suspended-Sediment Trends in the Missouri River Basin, 1993-2003," US Geological Survey Scientific Investigations Report 2006-5231, 2006.

[7] L. W. Hesse and W. Sheets, "The Missouri River Hydrosystem," Fisheries, Vol. 18, No. 5, 1993, pp. 5-14. doi:10.1577/1548-8446(1993)018<0005:TMRH >2.0.CO; $\underline{2}$

[8] US Fish and Wildlife Service, "Biological Opinion on the Operation of the Missouri River Main Stem Reservoir System, Operation and Maintenance of the Missouri River Bank Stabilization and Navigation Project, and Operation of the Kansas River Reservoir System," US Fish and Wildlife Service, Washington DC, 2000.

[9] National Research Council, "The Missouri River Ecosystem: Exploring the Prospects for Recovery," The National Academies Press, Washington DC, 2002.

[10] US Army Corps of Engineers, "Final Supplemental Environmental Impact Statement," Missouri River Fish and Wildlife Mitigation Project, 2003.

[11] L. W. Hesse, J. C. Schmulbach, J. M. Carr, K. D. Keenlyne, D. G. Unkenholz, J. W. Robinson and G. E. Mestl, "Missouri River Fishery Resources in Relation to Past, Present, and Future Stresses," Canadian Special Publication of Fisheries and Aquatic Sciences, Vol. 106, 1989, pp. 352-371.

[12] D. L. Galat, C. R. Berry, W. M. Gardner, J. C. Hendrickson, G. E. Mestl, G. J. Power, C. Stone and M. R. Winston, "Spatiotemporal Patterns and Changes in Missouri River Fishes," In: J. N. Rinne, R. M. Hughes and B. Calamusso, Eds., Historical Changes in Large River Fish Assemblages of the Americas, Symposium 45, American Fisheries Society, Bethesda, 2005, pp. 249-291.

[13] J. L. Funk and J. W. Robinson, "Changes in the Channel of the Lower Missouri River and Effects on Fish and
Wildlife," Missouri Department of Conservation Aquatic Series No. 11, Jefferson City, 1974.

[14] US Fish and Wildlife Service, "Amendment to the 2000 Biological Opinion on the Operation of the Missouri River Main Stem Reservoir System, Operation and Maintenance of the Missouri River Bank Stabilization and Navigation Project, and Operation of the Kansas River Reservoir System," US Fish and Wildlife Service, Washington DC, 2003.

[15] R. B. Jacobson and D. L. Galat, "Flow and Form in Rehabilitation of Large-River Ecosystems: An Example from the Lower Missouri River," Geomorphology, Vol. 77, No. 3-4, 2006, pp. 249-269. doi:10.1016/j.geomorph.2006.01.014

[16] US Fish and Wildlife Service, "Letter to the US Army Corps of Engineers Describing a Clarified Definition of Shallow Water Habitat," US Fish and Wildlife Service, Washington DC, 2009.

[17] US Army Corps of Engineers, "Missouri River Recovery Program Project Implementation Report with Integrated Environmental Assessment and Section 404(b)(1) Evaluation. Jameson Island Unit Shallow Water Habitat Restoration Project on the US Fish \& Wildlife Service's Jameson Island Unit-Big Muddy National Fish \& Wildlife Refuge," US Army Corps of Engineers, Washington DC, 2012.

[18] J. B. Brown, L. A. Sprague and J. A. Dupree, "Nutrient Sources and Transport in the Missouri River Basin, with Emphasis on the Effects of Irrigation and Reservoirs," Journal of the American Water Resources Association, Vol. 47, No. 5, 2011, pp. 1034-1060. doi:10.1111/j.1752-1688.2011.00584.x

[19] R. B. Jacobson, H. E. Johnson, M. S. Laustrup, G. J. D'Urso and J. M. Reuter, "Physical Habitat Dynamics in Four Side-Channel Chutes, Lower Missouri River," US Geological Survey Open-File Report 2004-1071, Columbia Environmental Research Center, Columbia, 2004.

[20] US Environmental Protection Agency, "Evaluation of Dredged Material Proposed for Discharge in Waters of the US-Test Manual: Inland Testing Manual. EPA-823-B98-004, February 1998," US Environmental Protection Agency, Washington DC, 1998.

[21] D. A. Beauchamp, D. H. Wahl and B. M. Johnson, "Predator-Prey Interactions," In: C. S. Guy and M. L. Brown, Eds., Analysis and Interpretation of Freshwater Fisheries Data, American Fisheries Society, Bethesda, 2007, pp. 765-842.

[22] E. H. Stanley and M. W. Doyle, "A Geomorphic Perspective on Nutrient Retention Following Dam Removal," BioScience, Vol. 52, No. 8, 2002, pp. 693-701. doi:10.1641/0006-3568(2002)052[0693:AGPONR]2.0.C $\underline{\mathrm{O} ; 2}$

[23] H. Ng, T. Mayaer and J. Marsalek, "Phosphorus Transport in Runoff from a Small Agricultural Watershed," Water Science and Technology, Vol. 28, No. 3-5, 1993, pp. 451-460.

[24] D. W. Blevins, D. Wilkison and S. Niesen, "Pre- and PostImpoundment Nitrogen in the Lower Missouri River," Hydrological Processes, in Press. 
[25] B. K. Woodward and D. L. Rus, "Characteristics of Suspended and Streambed Sediment Within Constructed Chutes and the Main Channel at Upper Hamburg and Glovers Point Bends, Missouri River, Nebraska, 2008," US Geological Survey Open-File Report 2011-1049, 2011.

[26] R. A. Smith, G. E. Schwarz and R. B. Alexander, "Regional Interpretation of Water-Quality Monitoring Data," Water Resources Research, Vol. 33, No. 12, 1997, pp. 2781-2798. doi:10.1029/97WR02171

[27] R. B. Alexander, R. A. Smith, G. E. Schwarz, E. W. Boyer, J. V. Nolan and J. W. Brakebill, "Differences in Phosphorus and Nitrogen Delivery to the Gulf of Mexico from the Mississippi River," Environmental Science and Technology, Vol. 42, No. 3, 2008, pp. 822-830. doi:10.1021/es0716103

[28] R. A. Rebich, N. A. Houston, S. V. Mize, D. K. Pearson, P. B. Ging and C. E. Hornig, "Sources of Delivery of Nutrients to the Northwestern Gulf of Mexico from Streams in the South-Central United States," Journal of the American Water Resources Association, Vol. 47, No. 5, 2011, pp. 1061-1086. doi:10.1111/j.1752-1688.2011.00583.x

[29] D. R. Wise and H. M. Johnson, "Surface-Water Nutrient Conditions and Sources in the United States Pacific Northwest," Journal of the American Water Resources Association, Vol. 47, No. 5, 2011, pp. 1110-1135. doi:10.1111/j.1752-1688.2011.00580.x

[30] R. B. Jacobson, D. W. Belvins and C. J. Bitner, "Sediment Regime Constraints on River Restoration-An Example from the Lower Missouri River," In: L. A. James, S. L. Rathburn and G. R. Whittecar, Eds., Management and Restoration of Fluvial Systems with Broad Historical Changes and Human Impacts, Geological Society of America Special Papers 451, 2009, pp. 1-22. doi:10.1130/2009.2451(01)

[31] J. W. Crites, Q. E. Phelps, K. N. S. McCain, D. P. Herzog and R. A. Hrabik, "An Investigation of Fish Community and Water Quality Compositions in an Isolated Side Channel of the Upper Missouri River," Journal of Freshwater Ecology, Vol. 27, No. 1, 2012, pp. 19-29.

[32] J. Barras, S. Beville, D. Britsch, S. Hartley, S. Hawes, J. Johnston, P. Kemp, Q. Kinler, A. Martucci, J. Porthouse, D. Reed, K. Roy, S. Saptoka and J. Suhayda, "Historic and Predicted Coastal Louisiana Land Changes: 19782050," US Geological Survey Open File Report 03-334, National Wetlands Research Center, Baton Rouge, 2003.

[33] Gulf Coast Ecosystem Restoration Task Force, "Gulf of Mexico Regional Ecosystem Restoration Strategy," 2011, $119 \mathrm{p}$. http://www.epa.gov/gcertf/pdfs/GulfCoastReport_Full_1204_508-1.pdf 